This article has been accepted for publication in a revised form in Enterprise \& Society https://www.cambridge.org/core/journals/enterprise-and-society. This version is free to view and download for private research and study only. Not for re-distribution, re-sale or use in derivative works. (C) Cambridge University Press.

\title{
This Thing Called GOODWILL: The Reynolds Metals Company and Political
}

\section{Networking in Wartime America}

Andrew Perchard, University of Stirling

\section{Abstract:}

This article examines the Reynolds Metals Company's political networking activities in Washington D.C. and the state capitols of the US South in the 1940s and 1950s. It argues that Reynolds' astute recruitment of senior staff from federal and state government, adept building of elite networks in the legislative and executive branches, and judicious espousing of key political rhetoric (antitrust, regional development, national security) and nurturing of Democratic circles in the South, was crucial to their rise from a new entrant to US primary aluminum production during World War II to the second largest national producer by 1946 and a major global player by the mid-1950s. This same political networking was critical to maintaining that advantage after WWII in the face of competition from the Aluminum Company of America (Alcoa) and Canadian multinational the Aluminium Company of Canada (Alcan). "Wartime" - covering WWII and into the Cold War - and the legacy of state intervention in the US from the early twentieth century until the 1960s, including the New Deal, provided a fertile context for this strategy. RMC's success owed much to founder Richard S. Reynolds Snr's acumen, networks and social capital, and his experiences and connections accrued from working from his uncle, and noted tobacco magnate, R. J. Reynolds. The article offers insights into the nature of US business-government relations.

Goodwill means giving people reasons to think well of us, so that they will prefer to do business with us. Our Goodwill Division is the biggest thing in Reynolds Metals, and each of us is part of it. Goodwill is our most precious possession... It needs constant, daily 
entries or the ink will fade. Let's take a good look at this thing that controls our jobs, our future, and our security. Let's look at our most precious asset.'

In March 1949, Reynolds Metals' vice-president Keen Johnson wrote to Company president, Richard S. Reynolds, Jnr., enclosing the booklet from which this extract is drawn. Johnson informed his boss that the rationale for This Thing Called GOODWILL “. $\ldots$ is that we can improve our public relations and build up good will only by impressing upon each member of the Reynolds Metals organization the fact that we all have a responsibility to work daily at this important task". Whilst the handbook was intended to instruct all employees on customer relations, it understated Reynolds Metals' most significant deployment of goodwill, in their cultivation of political networks especially in Washington D.C.. As one of the foremost agents of the Company's political activity, former Kentucky Governor Johnson was being modest about their achievements. ${ }^{3}$

This article examines the Reynolds Metals Company's political networking in Washington D.C. in the 1940s and 1950s, setting this against the context of "wartime" and the legacy of growing state intervention since the early twentieth century. It examines the Company's development of its public affairs capabilities through the recruitment of former federal and state officials, nurturing of networks in government departments and amongst legislators on Capitol Hill, and their deployment of their regional identity and key policy rhetoric (antitrust, regional development and national security) to cement relationships and gain influence and competitive advantage.

It was RMC's capability in building and deploying these political connections in Washington D.C. (as well as in the state capitols of the South), that allowed them to break into primary aluminum production during WWII and retain that position. Founded in 1928 to produce 
aluminum foil for cigarette packaging, prior to World War II, the Reynolds Metals Company (RMC) owned no primary aluminum production facilities and limited downstream capacity. By 1944 they controlled primary aluminum smelters or extrusion plants and rolling mills, as well as access to upstream supplies, and their share of global aluminum production reached 7\%. By 1946, they accounted for $30 \%$ of global output. ${ }^{4}$ The political goodwill they had accrued by the end of WWII afforded Reynolds Metals sufficient competitive advantage to become the second largest US primary aluminum producer and a major competitor to the Aluminum Company of America (Alcoa), who had hitherto monopolised aluminum production in the US and been one of the two first movers (and dominant players) in the global industry. Alcoa had enjoyed considerable political patronage from WWI, especially under Presidents Harding, Coolidge and Hoover. ${ }^{5}$ As testament to Alcoa's continued market dominance and influence, as late as 1937 they had been able to block US Justice Department anti-trust investigations with support from the War Department and managed to successfully evade charges of acting as a trust in 194I. However, by the close of WWII, with political support, Reynolds (and Kaiser) had gained control of Alcoa's Hurricane Creek and Baton Rouge alumina refineries, Spokane, Tacoma, and Troutdale smelters, and the Jones Mill, along with Alcoa's patents. ${ }^{6}$ In such a highly integrated and capital-intensive industry, their political connections also allowed Reynolds Metals to secure access to upstream supplies of bauxite and production facilities for alumina (aluminum oxide) so that by the mid-1950s, Reynolds had extended their control within the global aluminium supply chain to $16.4 \%$ and $16.9 \%$ respectively of global bauxite and alumina output by $1955 .^{7}$

Reynolds' Metals' success was such that by December 1946, the J Walter Thompson (JWT) Agency, handling RMC's public relations, reported to Richard S. Reynolds Jnr that their brokers Bache \& Co, "are pretty high on Reynolds". JWT and Bache's confidence stemmed, 
in large part from the political patronage that RMC were perceived to enjoy: "The Government's large investment in Reynolds... may serve as a sort of reinsurance against unlikely attempts by others to 'throttle' Reynolds."' The value of the Company's investment in its public affairs capabilities and political networks was demonstrated again in the battles of the late 1940s and 1950s, as Alcoa sought to reassert itself and as the Aluminium Company of Canada (Alcan) sought import tariffs reductions on Canadian aluminium and further US government contracts. Reynolds' ascendancy in the global industry was crowned in 1959, when, with the UK's Tube Investments, it took control of another of the first movers in the global industry, the British Aluminium Company Ltd (BACo), who still monopolised aluminium smelting in the UK and the British Empire, as well as holding the exclusive British rights for aluminium smelting. ${ }^{10}$ Reynolds Metals rise from a modest and largely regional producer and supplier of aluminum foil to the tobacco industry to a dominant force in the North American, and global, aluminum, industry over the space of just over a decade was nothing short of meteoric." That success was built on this investment in and deployment of political connections.

RMC's success was initiated by their founder Richard S. Reynolds Snr., who demonstrated considerable prescience and political acumen in his recruitment to senior management positions in the Company former well-connected and highly capable public servants, such as Keen Johnson. Reynolds Snr also understood from experience the importance of timing and of deploying key salient political themes (antitrust and regional development) and recognising sectional interests. He used his family pedigree, their connections to the Democratic National Committee (DNC) and Reynolds' location as a Southern firm to their advantage at a time when both political houses were dominated by senior Southern Democrats. 
However, this success was equally contingent upon the historical context. The success of Richard S Reynolds Snr's, and RMC's, transactions with executive and legislature (and the receptiveness of their approach and rhetoric) were reliant on a long tradition of southern Democratic patronage of business from the early twentieth century onwards, and southern Democrats dominance of Capitol Hill by this period. It was also directly aided by the legacy of state intervention under both the Hoover administration, notably the Reconstruction Finance Corporation (RFC), and Roosevelt's New Deal (through the Tennessee Valley Authority (TVA) and Bonneville Power Administration (BPA), as well as the US war economy.

For much of this period (the 1940s and 1950s), the US legally and politically was overshadowed by what Mary Dudziak has referred to as "War Time".'2 "War Time" did not end with WWII but continued into the Cold War and peaked again during the Korean War, accompanied by an infrastructure for financing, producing and distributing materiel. Between 1931 and 196I, US government purchases of goods and services rose from $12.1 \%$ to $20.6 \%$ (reaching a peak in 1944 of $46.3 \%$ ) and budgetary expenditure from $10.6 \%$ in 1927 to $29.6 \%$ in $1961 .^{13}$ As James Sparrow observed: "As the larger trajectory of federal spending, revenue, debt, employment, and military deployment in the twentieth century makes clear, the Second World War, building on but also superseding the New Deal was a critical turning point for the growth of federal government within American society." ${ }^{4}$ The US, "the Arsenal of Democracy", as FDR described it, produced two thirds of Allied munitions. ${ }^{15}$ Aluminum was a key strategic metal; its consumption and production grew dramatically during World War II and the Korean War driven by the demand for it above all in military aircraft manufacture. As the US Public Affairs Institute's Dr Dewey Anderson 
observed in 1951: "Aluminium has become the most important single bulk material of modern warfare. No fighting is possible, and no war can be carried to a successful conclusion today, without using and destroying large quantities of aluminium."16 As Mats Ingulstad has noted for aluminum, and Paul Tiffany for steel, this dramatic demand for both metals in wartime resulted in mounting government pressure for increased production and an expansion of industrial capacity to the advantage of smaller producers. ${ }^{17}$

Equally crucial were the opportunities arising for RMC out of state intervention under the Hoover administration and Roosevelt's New Deal, in terms of the recruitment of key personnel and the politics of antitrust and expansion of regional development opportunities. Whilst FDR's wartime accommodation with business saw a cooling of antitrust action (as it had for Woodrow Wilson's administration in WWI) and the New Deal, key members of the administration (notably Secretary of the Interior, Harold Ickes) remained ardent advocates and were closely tied to younger New Dealers who continued to pursue issues like antitrust. ${ }^{18}$ The recession of October 1937, and more specifically where monopolies were concerned Thurman Arnold's tenure at the Anti Trust Division (ATD) of the Department of Justice (1938-43), had also reignited arguments for an interventionist role for the state in the economy, notably around expanding production and in efficiency gains for consumers, alongside productivity priorities for the war effort. These proved advantageous for RMC (and were readily exploited by them). ${ }^{19}$ When former small businessman Harry Truman took office as President in April 1945, antitrust policy was renewed aided by the changes effected by Arnold at the ATD (as exemplified by the cases against both Alcoa and US Steel). ${ }^{20}$ 
Moreover, the commitments to regional development and industrialization arising from both the Hoover and Roosevelt administrations continued to advantage the South and were further enabled by the warfare state, not least given the control of the key committees of both the Senate and House of Representatives by powerful southern Democrats who dominated Capitol Hill at this time. Richard S. Reynolds Snr (and his successors and company officers) proved highly adept in their exploitation of the opportunities offered by that context - and their demonstration of their regional, patriotic, and antitrust credentials - to build organisational capabilities and sustainable competitive advantage. That Reynolds Snr, and RMC, were able to do this relied on their networks and social capital in the South, and their prudent recruitment of the key personnel, both of which increased their legitimacy with pivotal political actors in Washington D.C. (and state capitols of the South).

This article locates the Reynolds story's wider relevance, then considers the role of the Company's founder Richard S. Reynolds Snr, before considering their recruitment of key personnel pivotal to the success of their networking in Washington D.C. and the South. It then outlines their coalition-building with politicians and officialdom and how these connections were deployed before observing the Reynolds' families own political convictions and concluding.

\section{Reynolds and US business-government relations}

Beyond the intrinsic worth of the Reynolds Metals story both to US and global business history (especially that of the aluminum industry), it assumes a broader significance within debates in scholarly literature around business-government relations in the US, notably over development of an 'organizational society' in the $20^{\text {th }}$ century. ${ }^{21}$ Specifically, following the important work of Brian Balogh and Alan Brinkley, it notes the legacy of the New Deal (as 
well as reforms of the Hoover administration) in relation to the importance of the repositories of knowledge and skills within federal agencies and their transfer to the private sector (illustrated most prominently by figures such as David E. Lilienthal and Tommy "the cork" Corcoran). ${ }^{22}$ However, it also underlines the importance of a longer trajectory of progressive reformism. It also adds further detail to the voluminous history of the US warfare state of this period, as well as to that around regional industrialization. ${ }^{23}$ More broadly it contributes a historical case study to the social science literature around the importance of networks and social capital to family business survival and corporate political activity. ${ }^{24}$ Reynolds sophisticated development of its public affairs machinery took place at a time when lobbyists were relatively scarce in Washington D.C. (as late as 1956, there were 615 registered lobbyists in the DC area; by 2016 , this had risen to 10,462 ) and before Lester Milbrath's definition of lobbyists in his paradigm-shifting 1963 book. ${ }^{25}$

The Reynolds Metals Company's story, like that of the infinitely better-known account of Henry J. Kaiser, provides valuable insights into the nature of US business-government relations and corporate political activity. Like Reynolds, Kaiser exploited the opportunities presented by WWII (as well as the opportunities presented by the Hoover administration and the New Deal) to expand his business empire from construction into shipbuilding, aircraft manufacture, and light metals production. Kaiser also built his empire by political networking at state and federal levels, famously declaring to journalists in July 1942:

Every time I take anybody to a shipyard, they want to see the ways and they think that is the shipyard. Well, that isn't the shipyard at all, and when you go to an aircraft plant, you want to see the garage they keep the planes in or build them in. That isn't the aircraft plant. I will tell you where the aircraft plant is and where the shipyard is: it starts in Washington. ${ }^{26}$ 
As Stephen Adams has observed of Kaiser: "[he] could not have achieved his success in shipbuilding, steel, dam building, or aluminum without a healthy relationship with the executive branch". ${ }^{27}$

Similarly, Reynolds Metals would not have achieved this without considerable political backing and substantial federal finance. Reynolds' dividends from the federal government included an initial Reconstruction Finance Corporation (RFC) loan to RMC of $\$ 15.3 \mathrm{~m}$ to construct the Listerhill smelter in Alabama (named after Alabama senator Lister Hill in recognition of his central part in securing the construction of it), and a further $\$ 2.5 \mathrm{~m}$ from the RFC's subsidiary, the Defence Plant Corporation (DPC), for a new extrusion plant at Louisville, Kentucky. RMC's loans from RFC and DPC conservatively totalled around $30 \%$ of that disbursed by the two public bodies. Some historians of aluminium have accepted Richard S Reynolds Snr's version of events about his personal mortgaging of assets, alongside his far-sighted recognition of the threat posed by Nazi Germany and the need for aluminium as a lone voice in the wilderness, without recognising it as a well-rehearsed corporate narrative that portrayed the pater familias of the Company as a national saviour. ${ }^{28}$

This was a familiar trope amongst businessmen, who had benefited from federal support, to perpetuate the self-made myth and portray themselves as hampered by and in conflict with government. Similarly, Adams has noted that "Kaiser got a lot of mileage from portraying himself in conflict with the bureaucracy" ${ }^{29}$ Adams recounts the story of a US Chamber of Commerce dinner in 1934 at which successive businessmen demanded that government be kept out of business, while RFC chief Jesse Jones pencilled down how much each had been loaned by the Corporation. As Adams noted: "Businessmen are traditionally mute about opportunities government presents to them. At the same time, they loudly bemoan 
restrictions on their activities, such as those accompanying the federal government's rapid growth since the 1930s." 30

RMC's RFC and DPC loans were also offered at favourable rates. Moreover, in a highly energy-intensive process like aluminum smelting, it is highly questionable whether a newcomer like Reynolds would have fared as well without the subsidised power rates from the TVA for their Listerhill Plant or from the BPA which provided power to their Washington State and Oregon smelters at Spokane, Tacoma, and Troutdale. Despite Reynolds predictable complaints about power rates (partly as a negotiating position and in part to mythologise the vision of their founder, Richard S. Reynolds, Snr), TVA rates were half those paid by industrial customers in the US north-east. Equally, between 1940 and 1944 alone, RMC, and its subsidiaries and affiliates, secured $\$ 600 \mathrm{~m}$ in government contracts. They also benefitted from tax breaks at state-levels, such as for their bauxite mining operations in Arkansas. ${ }^{31}$ As Mark Wilson has recently emphasised, it was such state support, alongside that of labor unions, (not just business cooperation) that played a crucial role in the prosecution of the war and the growth of these companies. ${ }^{32}$

Reynolds and Kaiser bear comparison for several other reasons too. Both used their locations, respectively as southern and western businesses, to build political connections and elicit support in a sympathetic political climate. While Kaiser promoted himself as the "Builder of the American West", so Richard S. Reynolds Snr (and Reynolds Metals) profited from promoting their role as an industrial leader in the "New South". ${ }^{33}$ Reynolds' family connections to the DNC in the South were invaluable in a period when the US legislature was dominated by senior Southern Democrats. As Richard Bensel observed, "Deep South constituencies were over-represented within the Democratic Party and even more 
concentrated in the higher seniority of the separate committees." 34 This had a direct effect on the "deflection of federal spending toward the South". 35

Reynolds Snr, his sons and key Company executives, made it their business to court those senior legislators, as well as acquiring allies within FDR's administration. Equally both firms, while not active participants in the Department of Justice and Federal Trade Commission's cases against Alcoa, used antitrust sentiments to elicit support from amongst key and prominent Democrats. Besides being an observer of the cases against Alcoa, while working for his uncle, R. J. Reynolds, at Reynolds Tobacco, Richard S. Reynolds Snr had also witnessed the bitter antitrust cases over tobacco. ${ }^{36}$

Reynolds (and Kaiser) provide an example of the transfer of organizational capabilities (in the form of bureaucratic expertise and networks) from the public to private sectors through the shrewd recruitment of politicians and officials from government departments and agencies; in Reynolds' case cannily recruiting figures such as Keen Johnson, as well as others discussed here like Walter L. Rice, Marion Caskie, and Irving Lipkowitz.

If anything, Reynolds political machinery was much more sophisticated than Kaiser's. Reynolds avoided the controversy that later enveloped Kaiser resulting from the latter's highprofile association with prominent New Deal lawyer (and renowned lobbyist) Tommy "the Cork" Corcoran, by managing their political engagement in-house, although the scale of Henry Kaiser's enterprises and the brief consideration of him as a presidential prospect for the DNC made him more of a target. ${ }^{37}$ 
The Reynolds story contributes to wider debates amongst historians and political scientists about the character of business-government relations in the US between the "progressive era" and the Cold War, specifically the emergence of what Louis Galambos and Joseph Pratt characterised as a "Corporate Commonwealth", manifesting increasingly in the dynamics of US managerial capitalism identified by Alfred Chandler Jnr. Galambos and Pratt's Rise of the Corporate Commonwealth published in 1988 advanced the idea that US business and government reached a comfortable accommodation between the early twentieth century and the late 1970s. ${ }^{38}$ The Rise of the Corporate Commonwealth provided a popular outing for ideas that Galambos had advanced in a seminal article in Business History Review in 1970, sparking off a debate amongst historians and political scientists. ${ }^{39}$ In this, and subsequent related work, he advanced the notion that an "organizational society" emerged in the US in the $20^{\text {th }}$ century out of widespread managerial corporatism (in both business and government) that led to a more professionalised society and greater consensus between business and government. ${ }^{40}$ This was contiguous to a body of work from Ellis Hawley through to Michael Hogan charting the emergence of a "corporate liberalism"; a corporatism defined both on ideological and organisational grounds that sought, "a "middle way" between the laissez-faire of a bygone day and the paternalistic statism of an Orwellian nightmare':

In this system, partisan politics would give way to managerial expertise, public legislatures would yield some of their functions to private forums, and redistributive battles would dissolve in a material abundance in which all could share. ${ }^{41}$

Whilst such arguments attracted considerable support - and to some degree coalesced with Chandler's Parsonian-influenced work (although the doyen of business history never made such claims) - it was challenged on a number of grounds by historians and political scientists alike. 
Amongst the most profound charges against it were those levelled by Michael McGerr who questioned whether "an organizational society" ever existed in the US. More widespread was the charge, in the case of Galambos, that he was advancing a presentist and ahistorical argument. The limitations of the historical period under analysis and changes overtime which relied heavily on an interpretation of the progressive era - led some, notably Brian Balogh in I99I, to ask why the New Deal and World War II had not been more carefully considered. A considerable literature has emerged around the nature of public-private engagement in the US during WWII, and over the question of the existence of a militaryindustrial complex, since Balogh identified this lacuna. ${ }^{42}$

Alan Brinkley and Brian Balogh's cautioning against imposing "ironclad laws that governed organizational development" are born out in the Reynolds story, and in extant sectoral studies by business historians, which have helped to shed more light on this periodisation, and meaningful comparisons, as well as distinctions. ${ }^{43}$ In particular, a key feature of this has focused on the importance of contests over monopolies and antitrust action. Most apposite, and intrinsically related to the Reynolds case, is George Smith's deft discussions of the US government's antitrust actions against Alcoa. Alcoa was subject to long antitrust actions brought against it by the Department of Justice (in 191 I-12, 1924-1930, and 1937-45) and the Federal Trade Commission (during the 1920s), as well as being subject of enquiries of the Temporary National Economic Committee in the late 1930s. ${ }^{44}$ Paul Tiffany's outlining of the long running battles and accommodations between US steel producers and government over antitrust (with actions taken both by the Department of Justice and the Federal Trade Commission) under the presidencies of Taft, FDR and Truman also bears some comparison. There are synergies too with Richard John's study of US 
telecommunications, and the emergence of the Bell System, and antitrust interventions by the Interstate Commerce Commission and the temporary bringing of telephone and telegraph services under public control. Such studies underline the importance of understanding the implications of longer running concerns over monopolies, and how battles and accommodations between business and government shaped the outlook and strategic decisions of those businesses. As John has observed of the Bell System: "[It] was sustained in a corporate culture that had been nurtured by a distinctive configuration of governmental institutions and civic ideals. This corporate culture was not free-floating: rather, it was the organizational response to the structuring of a progressive political economy."45

A further aspect of the Reynolds story's contribution to this understanding of complexity around the "organizational society" is in multi-level governance by adding to further bodies of historiography on the regional aspects of the relationship of business and government, and on the personal politics of business leaders that affected these interactions with government. ${ }^{46}$

Reynolds Metals meteoric rise within the global aluminum industry was even more marked given the high capital costs, geographically-extended and vulnerable supply chains, and associational barriers to entry. As work by historians of global aluminum has underlined their ascendancy within the global industry was remarkable given the operation of an oligopoly and long running cartels throughout much of the first half of the $20^{\text {th }}$ century. ${ }^{47}$ Any other new entrants to this industry did so either as the subsidiaries of one of the first movers (or at the very least with a major share owned by one of them) or as a statesponsored corporation. The growing strategic importance of aluminum meant that the 
national industries were proximate to government (both as a major customer and to manage political risk) and subject to state intervention. ${ }^{48}$ The close ties between the first movers, and barriers to new entrants, was underlined pointedly by the hostility from the established order of the global industry when Reynolds (with the UK's Tube Investments) gained control of BACo after a bitter takeover over 1958-1959. ${ }^{49}$

To further clarify RMC's organizational behaviours and strategy, the article explores these in conjunction with understanding of elite networks and the social and cultural capital (notably through the nurturing of trust). This is also important in seeking to engage with social scientists working in the fields of corporate political activity, business-government relations, international business and strategy (including non-market varieties), which often lack allimportant historical contextualisation and case studies as increasingly noted by scholars in the field. ${ }^{50}$ So that whilst this is principally an historical article, explicit reference to this literature is important in encouraging inter-disciplinary dialogue. In a recent notable example of a historically-informed organization study, that of the Hilton hotel group, Maclean et al note the importance of: "skilled social actors of rhetorically intense argumentation, elite political networking, coalition-building and cultivating officialdom enabled them to interact to good effect in selected localities". ${ }^{51}$ In Hilton's case, this involved linking the expansion of their chain to promoting US Cold War policy agendas. Reynolds Snr, the company officers he recruited and his successors, demonstrated all of the behaviours identified for the Hilton group. Their nurturing of elite networks (politicians and officials) unlocked benefits for them and proved invaluable for achieving and maintaining competitive advantage. French sociologist Pierre Bourdieu described social and cultural capital as: "the aggregate of the actual or potential resources which are linked to possession of a durable network of more or less institutionalized relationships of mutual acquaintance and recognition". 52 Similarly Alejandro 
Portes described social capital as accrued trust and arising benefits from membership of social networks. ${ }^{53}$ Richard S Reynolds Snr benefitted from these "aces in a game of cards," as Bourdieu put it, "that define the chances of profit in a particular field." 54 The trust implicit in this social capital, as a number of scholars have noted, is critical to beneficial relationships with government. ${ }^{55}$ This article draws on understandings of trust as deployed by Sherylynne Haggerty in her study of transatlantic business networks in the $18^{\text {th }}$ and $19^{\text {th }}$ century, in particular the notions of "ascribed trust" (trust assumed from membership of certain networks and groups and assumed characteristics) and "process-based trust" (confidence built up over time by competency and goodwill). ${ }^{56} \quad$ As the article demonstrates, Richard S. Reynolds' background and his membership of key social networks afforded him "ascribed trust". Reynolds' recruitment of the accrued knowledge and skills of former New Deal officials, and nurturing of politicians, both opened up new networks and won the Company "process-based trust", as did their coalition building and rhetoric.

Consequently, understanding of RMC's success in political networking needs to start with Richard S. Reynolds Snr (his background, social milieu and relationships with key staff). It was his legacy that would pay dividends in establishing the organisational capabilities necessary for the Company to succeed in in Washington and the state capitols of the South, seen in particular in his astute selection and nurturing of key staff. These same staff would also mentor his own sons in public affairs. However, it is important to note that the depth of trust for Reynolds (and the Company) was founded on an understanding that his family, location, and personal politics were based on common values with their political allies and that therefore Reynolds' support of certain policy platforms was not simply transactional. Reynolds, much like other US businessmen of their generation, as Phillips-Fein and Zelizer observed, were: "Far from being concerned only with their individual firms and companies, 
business people consistently sought to shape political life throughout the post-World War II years..."57

\section{Richard S. Reynolds Snr: Architect of Success}

Writing in 1945 a senior executive of one of RMC's subsidiaries said of Richard S. Reynolds Snr that he had, “... a very certain undefinable characteristic awareness or subconscious intuition which leads him to act decisively before other people, including his own organisation, are aware of approaching circumstances." 58 This description of Richard S. Reynolds' legendary foresight, in part, reflected a potent organizational narrative about the father of the Company. Nonetheless, it was also a well-placed observation on Reynolds' acuity of vision. Reynolds' acumen was built on his considerable business experience, as well as the advantages afforded to him by his family reputation and political connections in the South.

As the favourite nephew of R J Reynolds (“R.J."), he acquired political acumen through the years spent working at Reynolds Tobacco between 1903 and 1912. Through the Reynolds family [see figure I] connections, he was initiated into social networks, which included leading Democratic Party figures in the South - such as Woodrow Wilson's Secretary of the Navy, Josephus Daniels (an old friend and business associate of R. J.'s) - as well as prominent businessmen of all political hues (notably James B. ("Buck") Duke of the American Tobacco Company). As an indication of the Reynolds' family's place in the DNC machinery of the South, Richard S Reynolds Snr's cousin, Dick Reynolds, was attributed with financing FDR's second successful Presidential campaign. ${ }^{59}$

\section{[INSERT FIGURE I HERE]}

It was also while working for R. J. that he witnessed first-hand the Department of Justice's successful antitrust action against American Tobacco in 1911 (the same year that they won 
an even more famous victory against Standard Oil) against mounting federal and state action against monopolies with the passage of the Interstate Commerce Act in 1887 (in direct response to Rockefeller's trust and leading to the formation of the Interstate Commerce Commission) and the Sherman Antitrust Act in 1890. As Tony Freyer observed, 1911 was an auspicious year for federal antitrust actions and saw an intensified period of suits. The following year (1912) saw the passage of two further important milestones in US antitrust action, with the constitution of the Federal Trade Commission and the Clayton Antitrust Act. ${ }^{60}$ Besides absorbing the lessons of the antitrust actions, Richard S Reynolds Snr's association with public enterprise enthusiast Josephus Daniels meant it was also possible that he was also conversant with the details of Daniels' actions as Navy Secretary in setting up of a government owned and operated armour plate plant and transferring Marconi's patents for the radio under American control. ${ }^{61}$ It is also likely that it was through Daniels that RSR Snr met RMC's longest-running senatorial ally, Lister Hill, for whom the former Navy Secretary was a mentor. ${ }^{62}$

Aside from his connections through R. J. to southern Democratic circles, the Reynolds name carried considerable cultural, social, and symbolic capital in the South, evoking economic development in the "New South" after Reconstruction. These lent him considerable "ascribed trust", based on assumptions carried with that lineage, crucial to smoothing his way in these circles. ${ }^{63}$ Richard S Reynolds Snr was also able to link to the old South too; as a 17-year-old Virginia Military Institute cadet, his father, Abraham D. Reynolds, had enlisted in the army of the Confederacy and ended the war as a cavalry major. ${ }^{64}$ This location within an identifiable southern family was crucial to admitting him to social networks and unlocking social capital. It was exhibited both by the circles in which he moved and the cultural symbolism of practices 
in this social milieu. Richard Reynolds Snr understood the value of his power base in the South and how to deploy that to effect.

Richard Reynolds Snr also learned valuable lessons about social networks, trust and loyalty (and conversely the risks when these were breeched) from bitter personal experiences with his own previous endeavours during WWI and with US Foils and ultimately Reynolds Metals also provided him with further. He had co-founded US Foils with his father and Reynolds Tobacco but subsequently fell out with the latter over rights to the Company. ${ }^{65}$ As a result Reynolds Snr placed great stock in loyalty, vesting considerable power and responsibility in professional managers (in whom he entrusted both the success of the Company and the career development of his sons). This "bonding" of family was replicated in the "bridging" of social networks with trusted Company officials and political allies. ${ }^{66}$ Its success was visible from family succession within the Company, and the loyalty of its key officers. It was also evident in RMC's enduring political relationships. For RMC, the close familial relationship that RSR Snr nurtured with his sons (who all went on to senior roles in the Company), and other leading officers, was key to successful succession. RMC was characterised by close integration of family ownership and management into the 1970s. The Reynolds family continued to maintain ties between ownership and management of the Company up until its merger with Alcoa in 2000; RSR Snr's youngest son, David Reynolds, stepped down as President in 1995 but continued as Chairman, whilst RSR Snr's great-grandson, Richard Samuel Reynolds IV remained a group marketing manager for RMC and MD of the Reynolds Trust. ${ }^{67}$

Richard S. Reynolds' acuity was evident in his shrewd selection of the key Company personnel from the late 1930s onwards. He recognised the social networks, and the knowledge and managerial skills, that these former officials brought with them. His memory of past battles 
also informed the recruitment of these key Company officers, his coalition building, and use of political rhetoric. His (and the family's) loyalty to these key RMC officers was reciprocated; all would remain for the Company, with brief periods away (mostly for senior government service), for life.

While RMC's success was undoubtedly contingent on the context of more recent New Deal politics and the warfare state, Richard S Reynolds Snr's social networks and observations of earlier antitrust battles cast a long shadow over his approach. Similarly, as the next section indicates, Reynolds' persuasiveness in political circles also relied on their personal credibility in coalition building. However, while this was to partially transactional, it also reflected the personal politics of the Reynolds family and key Company officers.

\section{Building organizational capabilities}

Richard S. Reynolds Snr's perspicacious recruitment of key senior personnel from the late 1930s onwards demonstrated an acuity to the capabilities that Reynolds Metals would need to succeed in the political climate in which they were operating. These key figures brought with them years of experience and skills of operating in the political arena or government service, as well as valuable networks, which could open doors for the Company in Washington D.C., as well as in other parts of the South. As such they represented part of the wider transfer of valuable skills and knowledge between the public and private sectors as a legacy of increased role of the state in the economy. ${ }^{68}$ In this RMC (and other companies) was also aided by the dominance of the executive and legislature by southern Democrats throughout much of this period and the departure of highly able and brilliant public servants for the private sector; some of them frustrated at the lack of progress they had been able to make in government agencies to thwarting monopolies or aiding regional development. The most 
prominent example of this exodus being David E. Lilienthal, the lawyer who as a director, vice chairman and chairman of the TVA played a crucial role in advancing New Deal policies (and subsequently served as Chairman of the United States Atomic Energy Authority), leaving government in 1950 having served under both FDR and Truman. ${ }^{69}$

As Ken Lipartito noted of American business, "from its earliest years, big business has needed lawyers". ${ }^{70}$ More specifically, as Peter Irons observed, the New Deal was a "lawyer's deal". Ironically Richard S. Reynolds Snr's uncle R. J., had counselled him to abandon his legal studies at the University of Virginia to join him in business. However, R S Reynolds quickly recognised lawyers as an asset, not least having witnessed the anti-trust case against Buck Duke, and R J's battles against Duke and American Tobacco. ${ }^{72}$ Richard S. Reynolds would also have been well-versed with the Department of Justice's well-publicised cases against US Steel (I9II$1920)$ and, of course, against Alcoa (I9II-12, 1924-1930, and 1937-45). ${ }^{73}$

Amongst his shrewdest appointments was a former ATD lawyer, Walter Lyman Rice, who had served as Special Assistant to the Attorney General on antitrust action against Alcoa. A Minneapolis native, Walter Rice had extensive experience leading ATD antitrust cases, having joined straight out of Harvard Law School in 1928 (unusually for Reynolds, Rice was a lifelong Republican). Rice was marked out as a talented young lawyer with the Staff News of the Antitrust Division noting in 1936: "When a person wins praise on the pages of "The Nine Old Men" [the US Supreme Court] ... it is time to sit up and take notice. But those who know him were not surprised when they read the flattering tribute given to Walter L. Rice..." ${ }^{, 74}$ In appealing to Rice, Reynolds Snr was speaking not just to a supremely talented ATD lawyer (with a close familiarity of the Alcoa antitrust case) but as someone who believed in breaking monopolies. Replying to antitrust campaigner, and Texas Congressman, Wright Patman in 
1938, Rice declared: "I am sympathetic with the work you are doing and I am anxious to help you in any way that I can", ${ }^{75}$

Rice was subsequently joined by fellow ATD refugee, Irving Lipkowitz, who had worked with him on the Alcoa case. Lipkowitz was also a passionate New Deal liberal and antitrust advocate who also joined the Department of Justice after graduation from New York University in economics in 1934. Lipkowitz and Rice's motivation for joining Reynolds may also have stemmed from the humiliation that the ATD suffered at the hands of Alcoa and their counsel. ${ }^{76}$ While Smith speculates that it was this experience that may have prompted Lipkowitz to join Reynolds in the early 1940s, another explanation may lie in the state of the ATD; despite renewed interest from the White House in anti-trust matters by 1937 and 1938 the ATD, "simply had too much to do and too few resources", although after the arrival of Thurman Arnold, it saw a renewed sense of purpose and change in antitrust philosophy. ${ }^{77}$ Meanwhile FDR was encouraging cooperation between business and government. An equally important factor was very probably RSR Snr's persuasiveness, adroitness, and his own views on monopolies.

A further shrewd appointment to the Company in 1940 was Alabamian Marion M. Caskie. Caskie had just stepped down as chairman of the powerful Interstate Commerce Commission (ICC) and on FDR's National Emergency Council (NEC). He was a former assistant federal coordinator of transportation (director of state docks in Mobile, Alabama). ${ }^{78}$ RSR Snr's recruitment of Caskie exhibited considerable acuity at a number of levels. Given Caskie's position at the ICC (and as a former federal coordinator of transportation) - which controlled freight rates and regulated telecommunications as well as the railways - and the integrated supply chainrequired for aluminum production with plants spread over the US, this was a 
shrewd move. Besides which, Caskie's place on FDR's NEC (re-formed in 1935 to oversee the delivery of the New Deal programmes) also provided Reynolds with valuable political connections in the White House. ${ }^{79}$ Caskie had also worked with Reynolds' most enduring political ally on Capitol Hill, and fellow Alabamian, Senator Lister Hill, on the ICC, in attempting to secure more preferential freight rates for southern businesses, all part of attempts to further animate regional industrialization. ${ }^{80}$

A further sagacious short-term engagement was that of Frenchman Louis Marlio, stranded in wartime Washington by Nazi occupation of his country. The former head of the international aluminium cartel, and the senior figure in the French aluminum industry, Marlio helped RMC in brokering aluminium contracts with the British Purchasing Commission. Bertilorenzi argues that Marlio planned Reynolds post-war strategy. This is quite possible from a commercial standpoint (given his extensive knowledge and connections in the global industry). However, this overlooks the importance of the political environment to RMC's ascendancy. ${ }^{81}$

With the exception of brief periods of public service (which can only have served to renew the Company's political influence as well as ensuring their enduring loyally), Caskie, Johnson, Lipkowitz and Rice would remain with Reynolds Metals for the remainder of their careers. Marion Caskie, as RMC vice-president, ran their Washington office from 1940 until retirement in 1956. Keen Johnson remained a VP with the Company (with the brief interlude of 1946-7 as Truman's Under Secretary of Labor) from 1944 until his retirement in 196I, providing invaluable political service. Similarly, with a brief interlude as US Ambassador to Australia from 1969-73, Walter Rice remained with the Company until his retirement, as did Irving Lipkowitz (who remained an authority on monopolies). The attraction for them of joining Reynolds Metals was no accident but owed much to the possibilities of continuing the 
commitment of antitrust ideals and regional development through the Company. As with his political allies, Richard S. Reynolds Snr's commitment to issues such as antitrust and southern industrialization and regional development bought their trust and loyalty in him. His confidence in them, as well as financial generosity, care and interest, assured him (and the family) of their long service and enduring loyalty as demonstrated by correspondence with him and his son, Richard S Reynolds Snr who succeeded his father to lead the Company. ${ }^{82}$ In a letter to RSR Snr and Jnr, while serving as Under Secretary of Labor from 1946-7, Johnson declared: "[I] shall always be eager to demonstrate my appreciation... I miss you and the zest of being a member of the great Company you have builded [sic]." ${ }^{83}$ While Marion Caskie declared in a letter to RSR Snr in 1949: “As you must know, there is nothing I wouldn't do for you. In fact, I would hate to be tempted as I might be inclined to even scuttle a ship if by doing so I could aid you personally in any way"; a delicious irony given Caskie's role in helping them win defence contracts! ${ }^{84}$

For Reynolds not only did this coterie of most trusted advisors bring specific valuable knowledge and helped tutor his sons to lead the business but further extended political influence. These bonds of loyalty and trust ensured continued access to power brokers in Washington; so that when Marion Caskie retired he recommended as his replacement Edd Hyde who had previously worked on the staff of Alabama Democrat, and subsequently House Speaker, William Bankhead before working for Senator Sparkman. Senator Lister Hill underlined the value of Hyde's appointment in a letter to Richard S Reynolds Jnr (while informing him about the progress of a project before the Senate Appropriations Committee in which RMC had an interest):

I want to tell you... that you are really to be congratulated on getting Edd... [I] have known Edd for many years, including the years he served in the office of Speaker Bankhead, 
with Congressman Carter Manasco and with Senator Sparkman. He is extremely able and a wonderful fellow... We will certainly miss Edd on Capitol Hill, but our loss is your gain. ${ }^{85}$ Like his predecessors, Hyde remained with the Company for the rest of his career, as did his wife.

Alongside Richard S. Reynolds Snr's own accrued experience and acumen, his investment in his brain's trust of Caskie, Johnson, Lipkowitz and Rice would pay the Company enormous dividends for years in building political networks on and cultivating officialdom in the Capitol and the South.

\section{Capitol Allies: Building Networks and Coalitions}

These key Company officers' knowledge and skills were essential to building the political and official networks that afforded them greater influence in Washington D.C. (and state capitols) and ultimately allowed to consolidate their position as a national (and international) aluminum producer. If the Reynolds Metals Company could rely on "ascribed trust" based on family connections and regional location, then their employment of respected erstwhile public servants would build a "process-based trust" based on competency. ${ }^{86}$ That this was successful relied on their carefully nurtured relationships with powerful senior southern Democrats who dominated both Houses from the mid-1930s into the 1960s: Lyndon Johnson (Texas); Richard B. Russell (Georgia); John Sparkman (Alabama); Carl Vinson (Georgia); John L. McClellan (Arkansas); Estes Kefauver (Tennessee); J. William Fulbright (Arkansas); and above all the "Statesman from the South", Senator Lister Hill. ${ }^{87}$ Similarly, Reynolds Metals cultivated strong links in the state capitols where they operated plants. 
This political support was reciprocated with endorsements and campaign finance from Reynolds. ${ }^{88}$ Reynolds rhetorical appeal to these politicians (on issues like antitrust, regional development, and national security) was also, in part, revealed by these southern Democrats' platform and overlapping interests: "The success of these issue-orientated politicians was founded on a number of factors... These include infrastructure politics, a common-man popular appeal, the relative prosperity of southern states and their newfound ability to match New Deal spending..." ${ }^{89}$ The firm's contacts and links were cemented at events like the DNC's Jefferson-Jackson dinners (an influential forum at which presidential hopes have been made and broken), of which RSR Snr and his sons were major backers. At the 1952 dinner for Adlai Stevenson's presidential campaign, for example, Lister Hill, RSR Jnr, Keen Johnson, and Marion Caskie, shared a table with Congressmen and Governors from Alabama, Arkansas, Kentucky, Mississippi, and Virginia. ${ }^{90}$

Reynolds' public espousal of the rhetoric of antitrust and regional development also won them the support of FDR's powerful Secretary of the Interior (1933-1946), Harold L. Ickes. Ickes was an invaluable ally to Reynolds both in and out of office. Ickes oversaw the Public Works Administration and remained the most prominent and powerful New Dealer in FDR's administration by 1940. He welcomed RMC's entry to US aluminum production, not least through his support of advantageous power contracts to the Company, as Ickes reminded RSR Jnr in 1950 of his greatest favour to the Company through:

... I would like to reminisce a bit with you about your company and the progress that you have made since you and I agreed upon a contract for power generated at Bonneville. Much water was gone over the dam - not necessarily Bonneville - since that day and I gather that your company has greatly prospered, which, of course, gives me a feeling of satisfaction in that it justified my judgment that your company could turn out aluminum if 
given the opportunity which, in the particular instance referred to, meant hydroelectric power at a reasonable rate. ${ }^{91}$

With such an energy-intensive process as aluminum production, the negotiation of favourable BPA contracts ensured the profitability of RMC's Washington State and Oregon smelters. Ickes' continued support for RMC arose because of their support for antitrust and regional development (and for the New Deal legacy). After leaving office, they supported in each other's reputations from public attacks. Ickes continued, through his column in the New York Post, to be influential, seeing himself as a defender of the New Deal's legacy. ${ }^{92}$ Ickes was also trying to protect his personal reputation and legacy from attacks from columnist Drew Pearson. ${ }^{93}$ Similarly when Pearson slighted Reynolds in January 195I, Marion Caskie enlisted Ickes to rebut Pearson's misrepresentation. Caskie testified to RSR Snr, and RMC's, New Deal and patriotic credentials, while highlighting Ickes' own important role. ${ }^{94}$ The timing of this could not have been more important to Reynolds from a reputational perspective while they were seeking to defend their domain in discussions over government contracts and resisting Alcan's encroachment into US markets.

Reynolds Metals' competency, and specifically the knowledge and skills of Johnson, Caskie, and Rice, would be as crucial in building networks within officialdom, such as with the branches of the armed services supply departments. As their network and reputation for competence increased so more contacts came their way. A memo from RMC's Washington office to the Company HQ in June 1944 explained their methodical approach to this, reassuring the board, "your Washington Staff is soliciting business, through project development, from the armed services and the services of supply":

In terms of the footworking: "Each small "unit" in the Navy, just as the Army, handles its business "through channels". As we follow our subject from unit to unit we find that have 
to tell our story over again in each unit, that is, we must introduce the Company, prove its financial responsibility, demonstrate capacity and "know how", explain the nature and location of plant equipment and generally build up confidence in our ability to do what we say we can. If you inadvertently miss one unit in the sequence you will have delay and trouble in your project. ${ }^{95}$

By June 1944, RMC's official networks already included over 50 prominent officials. This methodical approach paid off when, in July 1944, a US Army contact provided them with contact details for all of the key figures in the Army, Navy Department, USMC, and USAAF. ${ }^{96}$ RMC's attention to detail was also visible in their head-hunting of well-placed military personnel close to retirement. At an Army Ordnance Dinner in Philadelphia in February 1945, attended both by RSR Jnr and Johnson (who was speaking, alongside the US Army's Chief of Ordnance), Johnson scribbled next to the name of one of his fellow diners, Brigadier General D. N. Hauseman (responsible for equipping the army for readjustment), "in contract termination (Pentagon)". ${ }^{97}$

To further smooth discussions with the armed services, Reynolds ensured that they also enlisted the support of congressmen who covered the districts that might benefit from new plants. In September 1944 after a meeting with Brig. Gen. Minton to discuss approval of the rubber development program (in which RMC had a stake) by the Combined Chiefs, RMC's Washington Office reported:

Congressman Charles R. Clason represents the Springfield, Massachusetts District in the House. In view of the establishment of the Reynolds Casting Plant at Springfield, Governor Johnson thought it wise that Reynolds representatives formally pay their respects to Mr. Clason. By appointment, therefore, the Governor and I called at the New House Office Building and enjoyed a most cordial reception and a most helpful visit. ${ }^{98}$ 
RMC's attention to detail in cultivating networks recalls Henry J. Kaiser's famous reproach to one of his managers complaining about naval supply departments in underlining the importance of careful attention to identifying the correct personnel and building relationships of trust: "You know there is no such things as the U.S. Navy! It's just a bunch of guys down there in Washington. Now which one is your problem?"99

This mastery of procurement processes, and courting of defense and supply officials, and Washington committees, demonstrating competency, was also facilitated by trading goodwill with other industry contacts. While Reynolds and Kaiser competed over market share and segment, their coalition-building in the late 1940s and early 1950s would be invaluable when it came to battles with Alcoa and attempts to block Alcan's attempts to seize government contracts. Similarly, Donald A. White of the Aluminum Association shared his knowledge of changing defense machinery with Reynolds (and Kaiser) when they sought to persuade government of the need to stockpiling materials. White, noting that they had close contacts to Vannevar Bush, Chairman of the Research and Development Board of the Organization for National Security, suggested: "if you have any difficulty in your bauxite plans urge you call in for help". ${ }^{100}$

\section{Rhetorical Platforms and Deploying Assets}

Just how Reynolds conducted their dealings with senior Democratic politicians on Capitol Hill and the state capitols (as well as fellow industry figures), the rhetoric they used to enlist political support and forge coalitions, and how these political assets were deployed is set out in the ensuing discussions. RMC's judicious targeting of key legislators on Capitol Hill, deployment of political rhetoric (on antitrust, regional development, and national security), alongside their southern credentials, were a feature of their modus operandi. In this 
espousal of such rhetoric, Reynolds were not unique amongst southern businesses in the immediate postwar period. ${ }^{101}$

Their methodical approach was evident in their soliciting of senior southern legislators when seeking to purchase the Milledgeville Naval Ordnance Plant in Georgia from the Navy (and maintain the relationship with the Navy) in 1945. RSR Snr employed the rhetoric of both regional development and national security, and the Company's southern credentials, in a letter seeking support from senior Georgia Senator Richard B. Russell:

Our Company undertook this task because the Navy felt it was necessary to build a pool of skilled workers where they did not exist and the War effort would be benefited by this program. As a corollary, it has always been the desire of our organisation and of our family over several generations to assist in every possibly [sic] way the industrialization of the South as it a cause very dear to our hearts. ${ }^{102}$

Besides representing Georgia, Russell was also a powerful figure on the Senate Naval Affairs Committee. ${ }^{103}$ Over a thirty-year period, Russell's influence on Capitol Hill was arguably unparalleled, not least on matters of defence spending. He was responsible not only for securing contracts for his native Georgia but in distributing military spending around the states of southern allies. As Lyndon Johnson's White House Press Secretary, George Reedy, put it: In terms of legislative achievement, it would be impossible to find a national leader of greater stature than Richard B. Russell of Georgia. With Russell's blessing, almost any measure could pass the Senate. Against his determined opposition, it was doomed... He was recognized on both sides of the aisle as the preeminent Senator. ${ }^{104}$

Dean Rusk, Kennedy and Johnson's Secretary of State, considered Russell "the second most powerful man in Washington" for "twenty years". ${ }^{105}$ Seven months earlier, in March 1945, Keen Johnson had visited Congressman Carl Vinson, the powerful former chairman of the 
Congressional Naval Affairs Committee, with a gift of a cane mounted with an aluminum battleship tailor-made by Reynolds. An appreciative Vinson introduced Johnson to the naval liaison officer at Milledgeville and assured him that the award they had been awaiting would be made. ${ }^{106}$

Similarly, RMC used the rhetoric of regional development and national security to great effect in the state capitols of the South. When the Arkansas state legislature, and new Governor Sid McGrath, threatened a severance tax on bauxite in early 1949, Keen Johnson mobilised their local political networks to delay the threat, citing regional development: "I repeatedly asserted that the future expansion of Reynolds Metals Company had been pointed toward Arkansas and that an increase in the bauxite tax at this time would preclude such expansion within Arkansas."107

However, the greatest marshalling of Reynolds political networks and rhetoric, as well as coalition building, were displayed in the campaign to prevent a reduction in tariffs on imported aluminum (while conversely supporting these changes for bauxite imports) and government stockpiling of Canadian aluminum. Senators Hill, Stuart Symington, and Fulbright were critical to these negotiations throughout the 1940s and 1950s. Symington initially came into contact with Reynolds, in 1945, while chairman of the Surplus Property Board (SPB), which was responsible for selling off government war plants. Symington's experience, specifically his clashes with Alcoa, and its chairman, Arthur Vining Davis, while at the SPB made him a sympathetic audience. In Symington's subsequent roles, he promoted the importance of aluminum to military aircraft production and helped broker the deal awarding government contracts to Kaiser and Reynolds, as well as to Alcoa. ${ }^{108}$ Senator William Fulbright had served 
as an ATD attorney. By 1949, Senator Fulbright sat on the Senate Foreign Affairs Committee and from 1955 chaired the Senate Committee on Banking and Finance. ${ }^{109}$

Ranged against Reynolds (Kaiser, and the much smaller Fairmont Aluminum) was Alcoa, who saw the opportunity to eliminate the new competition. In building its coalition, RMC proposed to defend its position by promoting the imperative of an expanded US aluminum industry to meet defence requirements and the need for an aluminum stockpile. Writing to Richard S Reynolds Jnr in May 1947, Walter Rice proposed an unequivocal statement on these lines: "we should make it clear 'that we are advocating, first and above all else, the necessity for national security and preservation of the aluminum industry, which means a Government stockpile of aluminum pig". ${ }^{10}$ RMC then circulated this proposal around political allies couching it in the necessary rhetoric of national security and antitrust. They subsequently circulated this to all members of the Aluminum and Magnesium Industry Advisory Committee of the Army-Navy Munitions Board. Alcoa meanwhile vehemently opposed Reynolds' proposals - arguing instead for a bauxite stockpile - recognising that success of the former would strengthen the new entrants. Following this, Reynolds consolidated support amongst other smaller aluminium producers. "' Rice had already secured the support of the Aluminum Association, deploying the same arguments around monopoly and national security. ${ }^{1 / 2}$ With Alcoa's President, "Chief" Wilson, holding out, despite the majority of the committee supporting Reynolds' position, RSR Jnr marshalled the support of the other producers behind a reply drafted by Rice and Lipkowitz underlining national defense priorities and highlighting in the process concerns also about Canadian imports. ${ }^{1 / 3}$ By directing attention on to Alcan, it also implicitly drew a link to Alcoa's continued connection to its erstwhile Canadian subsidiary. This joint approach was further cemented at meeting between RMC and Kaiser Aluminum in July 1947, attended by RSR Jnr, Caskie, as well as Henry J Kaiser and Chad 
Calhoun (manager of Kaiser's Washington office and his main political aide), at which Kaiser agreed to support RMC's strategy for blocking lower tariffs (below those fixed by the 1930 Tariff Act) on imports of Canadian aluminum. ${ }^{14}$ Ultimately the Alcoa President was left isolated on the committee. ${ }^{115}$ As these negotiations reveal, RMC not only proved effective in protecting its own position but building consensus amongst and leading other aluminum producers to block Alcoa and Alcan.

Reynolds deployed the same tactics in responding to the opportunities arising from the passing of the Strategic and Critical Materials Stockpiling Act (1946), which sought to reduce dependency on foreign nations for strategic raw materials. However this also posed significant new threats with closer integration of raw materials supply and war production during WWII, through bodies such as US-Canada Material Board and the Combined Production and Resources Board, continuing into the Cold War through the Defense Production Administration (DPA), the Economic Cooperation Administration (ECA), and the Defense Materials Procurement Agency. ${ }^{116}$ This afforded the Aluminium Company of Canada (Alcan) even greater opportunities to compete in US markets. ${ }^{17}$ Alcan had enjoyed a "good war", receiving tax breaks and substantial loans from the Canadian government, as well as benefitting from generous loan rates and contracts from the British government. Alcan also enjoyed the active support of the Canadian "Minister for everything”, Clarence Howe, in their lobbying of Ottawa, London, and Washington. ${ }^{1 / 8}$

In the late 1940s and into the 1950s, RMC therefore campaigned against the awarding of government supply contracts to Alcan through the DPA and ECA, using their various political networks and deploying a rhetoric of economic nationalism. This was illustrated by Keen Johnson's appearance in September 1949 before the powerful Appropriations Committee to 
discuss the Senate Foreign Air Appropriations Bill. The committee was chaired by Tennessee Democrat Senator Kenneth McKellar, who was a fervent opponent of the New Deal (and therefore might look unfavourably on Reynolds). Keen Johnson met Sen. Lister Hill (who also sat on the Committee) in advance to agree on a series of leading questions which allowed Johnson to legitimately portray Reynolds as patriots, defenders of US jobs and regional economies, and a guardian against monopolies, before requesting that the "Appropriation Bill for the E.C.A be amended so as to require that the aluminum purchased by participating companies be purchased in the United States."|19

Again, in 195I, RMC deploying the rhetoric of antitrust and economic nationalism, enlisted Patterson and Fulbright to block Alcan's lobbying for Canadian imports to meet US defense requirements. Awarding defense procurement contracts to Alcan would be the equivalent Patterson stated of, "financing the Canadian Company's expansion". ${ }^{20}$ Fulbright used similar arguments against Canadian imports in the hearings of the Joint Defense Production Committee in May 1952. In March 1958 Richard S Reynolds Jr again sought to exploit Fulbright's position on the Senate Foreign Relations Committee by reiterating the Arkansas Senator's previous arguments against US government purchases of Canadian aluminium imports by the DPC. ${ }^{121}$ Ironically by this time, Reynolds was already planning their own foreign interventions with the hostile takeover of "first mover" British Aluminium (BACo) in 1959, primarily to seize BACo's Canadian subsidiary. For this, and other interventions in Jamaica and the newly independent Ghana in the 1950s and 1960s, RMC relied on the political support of former Illinois Governor Adlai Stevenson, whose presidential campaigns they had contributed to in 1952 and $1956 .^{122}$

Reynolds Metals' astute targeting and deployment of key political actors in Washington and the South and their use of political rhetoric to build coalitions was illustrated by the moves 
they made to secure the Midgeville naval station, as well as the battles with Alcoa to protect their gains, and to resist Alcan's greater penetration of US markets, through the late 1940s and into the 1950s.

\section{Conviction politics?}

Reynolds success in sustaining ties to the DNC, to senior figures on Capitol Hill, and in government hinged not only on their location, rhetoric and transactions, but also on a firm commitment to some of the political platforms on which these relied. The allegiances of vital Company officers Caskie and Johnson (as well as political allies like Lister Hill) to the Reynolds family were cemented by shared political allegiances and values. As Caskie remarked, acknowledging divergences in the DNC, in a letter to RSR Jnr over the $195 \mathrm{I}$ Jefferson-Jackson dinner: "The only new dealers or fair dealers will be Commissioner Aldridge, Wilson Wyatt, Arthur Grafton, Bob Jones, and myself, unless you can attend which will make it fifty-fifty". ${ }^{23}$

Throughout the 1960s, RMC retained close networks with the DNC, providing considerable support to JFK and Lyndon Johnson's campaigns, and enjoyed especially close access to LBJ as President. ${ }^{124}$ This did not prevent Reynolds and Kaiser being reprimanded by Johnson and his staff in 1965 over their attempts to raise aluminium prices against the backdrop of the escalation of the Vietnam War. ${ }^{125}$ As late as 1968, Richard S Reynolds Jr signalled his commitment to New Deal style policies when writing to LBJ of his support for the Great Society. ${ }^{126}$

What is striking, notwithstanding the transactional character of many of their discussions with their political allies, is that the Reynolds sons (like their father) continued to identify publicly with DNC New Dealers. This was, in contrast, to the "conservative businessmen and their 
allies" in the South of the 1950s and 1960s, pursuing a "conservative segregationist" agenda. ${ }^{127}$ Many of Reynolds senate allies supported segregation (in most cases enthusiastically, in others as a political expedient), while swimming against the tide in their commitment to New Deal institutions. However, RSR Jnr donated funds to the NAACP Legal Defense and Educational Fund in the early 1950s. ${ }^{128}$ Both of his sons were to enter Virginia Democratic politics, most famously J. Sargeant "Sarge" Reynolds who became Lt. Governor of the Commonwealth in 1970 aged 34 after a landslide victory only to die 6 months later. "Sarge" Reynolds counted substantial support from the Virginia Black Caucus because of his progressive views on race. Alongside his career in Reynolds businesses, Richard S. Reynolds Jnr's other son Richard S. (Major) Reynolds III was also elected to the Commonwealth's legislature and stood in the Democratic Primary for Lt Governor in 1977. ${ }^{129} \quad$ Without evidence of shared values, alongside these networks, it is questionable whether Reynolds would have cemented such strong political relationships.

\section{Conclusion}

In his 1956 address to the Newcomen Society, after the death of his father, RSR Jnr declared: “... our company is the product of my father's vision, his willingness to fight for what he knew was right, and... his peculiar ability to make opportunity out of crisis”. ${ }^{130}$ RSR Snr and his sons indubitably knew good press when they saw it. Nevertheless, RSR Jnr's eulogising was not far from the truth in emphasizing his father's acuity of vision. Richard S Reynolds Snr had identified the opportunity afforded by the context of wartime and revived state intervention in the 1930s (under Hoover and FDR) to break into aluminium production within a short space of time. 
There was no little irony in his grandson, Major Reynolds, declaring during the Democratic Primary for the Lt Governorship of Virginia in 1977 that the benefit of $80 \%-90 \%$ of his campaign being funded by his family, "is the independence it gives a candidate. You're not beholden to special interests". ${ }^{|3|}$ Reynolds Metals' success in breaking into US aluminium production was built on their astute recruitment of former politicians and officials, their methodical construction of networks in Washington D.C., and deployment of these both to build the business and manage threats to the infant business. As brokers Tucker, Anthony \& Co. recognised in July 1946: "The Reynolds management is resourceful and aggressive and in our view the industry is entering upon a period of favourable years..."132 Their building of coalitions with legislators (Hill, Russell, Vinson, Fulbright, Symington) and administrators (Ickes) was further cemented by their effective use of political rhetoric around antitrust, regional development, and national security. Reynolds were aided in their recruitment of key staff (Johnson, Rice, Caskie, Lipkowitz, and Hyde) and the rhetoric they deployed by the legacy of the New Deal and the context of wartime.

The lessons that RSR Snr learned at Reynolds Tobacco, and with U.S. Foils and RMC, and the social networks that he developed were key to his success. Reynolds understood the importance of extending the principles of family business, to bridge social networks and build loyalty through shared values, to developing a strong proactive relational political strategy. Throughout this process, RMC was well served by their Southern power base and pedigree. RSR Snr and his sons had considerable accrued social and cultural capital, which helped to build their political networks. Reynolds Snr, and the Company officers, that he recruited and that tutored his sons in the political arts. Reynolds Snr's acumen was revealed by his identification of the formidably impressive managers, recruited from government that oversaw negotiations in Washington and the state capitols: Keen Johnson; Marion Caskie; 
Walter Rice; and Irving Lipkowitz. The recruitment of this group was pivotal to the building of Reynolds' formidable Washington machinery. These opportunities were contingent on historical context and a supportive state, presented by the long politics of the New Deal and wartime. As such, Reynolds' story provides an illustration of the 'organizational society' and the transference of knowledge and skills from New Deal administration to the private sector.

It demonstrates the importance of cultivating these political and official networks, nurturing of coalitions, and deployment of rhetoric to cementing their success. As Mary Rose has observed contacts, goodwill, loyalty and trust play an integral role in family firm survival. ${ }^{133}$ Certainly, they illustrate the value that can extend from family ties into wider social networks underpinning a proactive political strategy. However, the strength of these, in RMC's case, was firmly rooted in the ability to demonstrate shared alliances and values. This was cemented over time by recruiting officials and political allies who shared those commitments and nurturing their loyalty and trust.

Bibliography of works cited

Adams, Stephen B. Mr. Kaiser Goes to Washington: The Rise of a Government Entrepreneur, Chapel Hill: University of North Carolina Press, 1997.

Anderson, Dewey H. Aluminium for Defense and Prosperity. Washington: Public Affairs Institute, 195I.

Badger, Anthony J. New Deal, New South: An Anthony J. Badger Reader, Fayetteville: University of Arkansas Press, 2007.

Bartels, Andrew H. "The Office of Price Administration and the Legacy of the New Deal, 1939-1946," The Public Historian 5 (1983), 5-29. 
Bertilorenzi, Marco. The International Aluminium cartel, I886-1978. The Business and Politics of a Cooperative Industrial Institution, New York: Routledge, 2014.

Bourdieu, Pierre. "Forms of capital," in Handbook of Theory and Research for the Sociology of Education, ed. by J.C. Richards, Greenwood: New York, 1983, 24I-258.

Bourdieu, Pierre. "The social space and the genesis of group," Theory and Society I4 (I 985): 723-44.

Cebul, Brent. "They Were the Moving Spirits": Business and Supply-Side Liberalism in the Postwar South," in Capital Gains: Business and Politics in Twentieth-Century America.

Philadelphia: University of Pennsylvania Press, 2017, I39-156.

Brinkley, Alan. "The New Deal and the Idea of the State," in The Rise and Fall of the New Deal Order 1930 - 1980, eds. S. Fraser and G. Gerstle, Princeton: Princeton University Press, 1989, 85-121.

Cook, James E. Carl Vinson: Patriarch of the Armed Forces, Macon: Mercer University Press, 2004.

David, Thomas and Westerhuis, Gerarda, eds., The Power of Corporate Networks: A Comparative and Historical Perspective, New York: Routledge, 2014.

Doh, Jonathan P., Lawton, Thomas C. and Rajwani, Tazeeb. “Advancing nonmarket strategy research: institutional perspectives in a changing world," Academy of Management Perspectives 26 (20I2): 22-39.

Dudziak, Mary L. War Time: An Idea, Its History, Its Consequences, New York: Oxford University Press, 2012.

Evenden, Matthew D. Fish versus Power: An Environmental History of the Fraser River, Cambridge: Cambridge University Press, 2004.

Fite, Gilbert C. Richard B. Russell, Jr. Senator from Georgia, Chapel Hill: UNC Press, 2002. 
Foster, Mark. Henry J. Kaiser: Builder in the Modern American West, Austin: University of Texas Press, 1989.

Freyer, T. Regulating Big Business: Antitrust in Great Britain and America, 1880-1990, Cambridge: Cambridge University Press, 1992.

Frynas, Jedrzej George, Chold, John and Tarba, Schlomo, "Non-market social and political strategies - new integrative approaches and interdisciplinary borrowings," British Journal of Management, 28 (2017): 559-574.

Galambos, Louis and Pratt, Joseph. The Rise of the Corporate Commonwealth: United States Business and Public Policy in the 20 $0^{\text {th }}$ Century, New York: Basic Books, 1988.

Gillespie, Michele. Katherine and R. J. Reynolds: Partners of Fortune in the Making of the New South, Athens, GA: University of Georgia Press, 2012.

Grinberg, Ivan and Hachez-Leroy, Florence, eds., Industrialisation et sociétés en Europe occidentale de la fin du XIXe siècle à nos jours, Paris: Armand Colin, 1997.

Hachez-Leroy, Florence. (1999), L’Aluminium français. L'invention d'un marché 19/1-1983, CNRS : Paris.

Haggerty, Sheryllynne. 'Merely for Money’? Business Culture in the British Atlantic, I 750-/8/5, Liverpool: Liverpool University Press, 2014.

Harvey, Charles and Maclean, Mairi. Business Elites and Corporate Governance in France and the UK, Basingstoke: Palgrave, 2006.

Higgs, Robert. Crisis and Leviathan: Critical Episodes in the Growth in American Government, Oxford: Oxford University Press, 1989.

Hillman, Amy J., Keim, Gerald D., and Schuler, Douglas. "Corporate Political Activity: A Review and Research Agenda," Journal of Management 30 (2004): 837-857.

Hooks, Gregory. "Guns and Butter, North and South: The Federal Contribution to Manufacturing Growth, 1940 - 1990,” in The Second Wave: Southern Industrialization from the 1940s to the 1970s, ed. Phillip Scranton, Athens, GA: The University of 
Georgia Press, 200I, 255-285.

Ingulstad, Mats. “'We want aluminum, not excuses!': Antitrust and Business-Government Partnership in the American Aluminium Industry, 1917-1957," in From Warfare to Welfare: Business-Government Relations in the Aluminium Industry, eds. Hans Otto Frøland and Mats Ingulstad, Trondheim: Akademika Forlag, 2012, 33-68.

Ingulstad, Mats. "National Security Business? The United States and the Creation of the Jamaican Bauxite Industry," in Aluminum Ore: The Political Economy of the Global Bauxite Industry, eds. Robin Gendron, Mats Ingulstad and Espen Storli, Vancouver: University of British Columbia Press, 2013, 107-137.

Irons, Peter H. The New Deal Lawyers, Princeton: Princeton University Press, 1982.

John, Richard R. Network Nation: Inventing American Telecommunications, Cambridge: Harvard University Press, 2015.

Jones, Geoffrey and Lubinski, Christina. “Managing Political Risk in Global Business:

Beiersdorf 1914-1990," Enterprise \& Society 13 (2012): 85-II9.

Lane, Christel. "Introduction: Theories and Issues in the Study of Trust," in Trust within and Between Organizations: Conceptual Issues and Empirical Applications, eds. Christel Lane and Reinhard Bachmann, Oxford: Oxford University Press, 2000, I-30.

Larson, A. "Network dyads in entrepreneurial settings: A study of the governance of exchange relationships”. Administrative Science Quarterly 37 (1992): 76-105.

Lawton, Thomas C., McGuire, Steven and Rajwani, Tazeeb. “Corporate Political Activity: A Literature Review and Research Agenda," International Journal of Management Reviews I5 (2013): 86-105.

Lipartito, Kenneth. "What Have Lawyers Done for American Business? The Case of Baker \& Botts of Houston," Business History Review 64 (1990): 489-526. 
Maclean, Mairi, Harvey, Charles, Clegg, Stewart. "Conceptualizing historical organization studies," Academy of Management Review 4I (2016): 609-632.

Maclean, Mairi, Harvey, Charles, Suddaby, Roy, and O'Gorman, Kevin. "Political ideology and the discursive construction of the multinational hotel industry". Human Relations 7I (2018): 766-795.

Martin, Peter. I Call on the Reynolds Brothers, Richmond: Reynolds Metals Company, I96I. McCutcheon, Andrew, and Michael P. Gleason. Sarge Reynolds In the Time of His Life, New York: Gleason Publishing Inc, 1996.

McKean, David. Tommy the Cork: Washington's Ultimate Insider from Roosevelt to Reagan, New York: Steerforth Press, 2004.

McKeever, Porter. Adlai Stevenson: His Life and Legacy, New York: Quill, 199I.

McKinstry, David. We Shall Overcome: The Politics of Civil Rights, May 1963 to August 1964, Saarbrücken: VDM Verlag, 2008.

Milbrath, Lester W. The Washington Lobbyists, Chicago: Rand McNally \& Company, 1963. Neuse, Stephen M. David E. Lilienthal: The Journey of An American Liberal, Knoxville: University of Tennessee Press, 1996.

Olsen, James C. Stuart Symington: A Life, Columbia: University of Missouri Press, 2003. Perchard, Andrew. Aluminiumville: Government, Global Business and the Scottish Highlands, Lancaster: Carnegie, 2012.

Perchard, Andrew, MacKenzie, Niall G, Decker, Stephanie, and Favero, Giovanni. "Clio in the business school: historical approaches in strategy, international business and entrepreneurship”. Business History 59 (2017): 904-927. Phillips-Fein, Kim, and Zelizer, Julian E., eds., What's Good for Business: Business and American Politics since World War II, New York: Oxford University Press, 2012. 
Portes, Alejandro. "Social capital: Its origins and applications in modern sociology". Annual Review of Sociology 24 (1998): I-24.

Reedy, George. The U.S. Senate: Paralysis, or a Search for Consensus? New York: Crown, 1986. Reynolds, Richard S. Jr. "Opportunity in Crisis": The Reynolds Metals Story, New York: The Newcomen Society, 1956.

Reynolds Metals Company. This Thing Called GOODWILL, Richmond, VA: Reynolds Metals Company, 1949.

Reynolds, Patrick and Shachtman, Tom. The Gilded Leaf: Triumph, Tragedy, and Tobacco Three Generations of the R. J. Reynolds Family and Fortune, Boston: Little Brown, 1989.

Rose, Mary B. "Beyond Buddenbrooks: the family firm and the management of succession in nineteenth-century Britain,” in Entrepreneurship, Networks, and Modern Business, eds. Jonathan Brown and Mary B. Rose, Manchester: Manchester University Press, 1993, I27-I43.

Smith, George D. From Monopoly to Competition: The Transformations of Alcoa, 1888-1986, Cambridge: Cambridge University Press, 1988.

Sparrow, James T. Warfare State: World War II Americans and the Age of Big Government, New York: Oxford University Press, $201 \mathrm{I}$.

Storli, Espen. "Cartel Theory and Cartel Practice: The Case of the International Aluminum Cartels, 190I - 1940,” Business History Review 88 (2014): 445-467.

Stuckey, John A. Vertical Integration and Joint Ventures in the Aluminium Industry, Cambridge, Mass.: Harvard University Press, 1983.

Swain, Martha H. Pat Harrison: The New Deal Years, Jackson: University Press of Missisippi, 1978.

Tiffany, Paul. The Decline of American Steel: How Management, Labour, and Government Went Wrong, Oxford: Oxford University Press, 1988. 
Tilley, Nannie M. The R. J. Reynolds Tobacco Company, Chapel Hill, University of North Carolina Press, 1985.

US Treasury, Final Report of the Reconstruction Finance Corporation, Washington DC: US Treasury, 1959.

Van der Veer Hamilton, Virginia. Lister Hill: Statesman from the South, Chapel Hill: University of North Carolina Press, 1987.

Walker, Spencer Weber. Thurman Arnold: A Biography, New York: New York University Press, 2005.

White, Graham and Maze, John. Harold Ickes of the New Deal: His Private Life and Public Career, Cambridge, Mass.: Harvard University Press, 1985.

Wilson, Mark R. Destructive Creation: American Business and the Winning of World War II. Philadelphia: University of Pennsylvania Press, 2016.

Woods, Randall Bennett. Fulbright: A Biography, New York: Cambridge University Press, 1995.

Woolcock, Michael. "The place of social capital in understanding social and economic outcomes," Isuma 2 (200I): I I-I7.

Newspapers

The Manassas Journal

The Montgomery Advertiser

The New York Times

The Washington Post

Dissertations

Ingulstad, Mats. "Winning the Hearth and Mines: Strategic Materials and American Foreign Policy, 1939-1953,” Unpublished PhD dissertation, European University Institute, 201 I. 
Klimas, Joshua E. "Balancing consensus, consent, and competence: Richard Russell, the Senate Armed Services Committee \& oversight of America's defense, 1955-1968," Unpublished PhD dissertation, Ohio State University, 2007.

\section{Archives}

The Lyndon Baines Johnson Library, Austin, Texas, USA, Papers of Lyndon Baines Johnson. Library of Congress, Washington D.C., USA, Papers of Harold L. Ickes.

Virginia of History \& Culture (VMHC), Richmond, Virginia, USA, Reynolds Metals Company Archive.

\footnotetext{
' Reynolds Metals Company, This Thing Called GOODWILL (Richmond VA, I949), I-2

${ }^{2}$ Reynolds Metals Company Archive (RCMA), MSS3 /R3395a /Series 4.7/ Box 38/ Folder I467, Letter from Keen Johnson to Richard S. Reynolds Jnr, 8 March 1949.

${ }^{3}$ Keen Johnson was Democratic Lt. Governor (1935-1939) and Governor (1939-1943) of Kentucky, and President Harry Truman's Under-Secretary of Labor (1946-1947).

${ }^{4}$ Bertilorenzi, The International Aluminium Cartel Table 10.2.

${ }^{5}$ Smith, From Monopoly to Competition.

${ }^{6}$ Ingulstad, "We want aluminum”, 33-68; Smith, From Monopoly to Competition; For Alcoa's dominance within share of global production and the supply chain, see: Lesclous, Histoire des sites producteurs d'aluminium, diagrams 16 and 17, tables 24,25 and 27.

${ }^{7}$ Stuckey, Vertical Integration, 84.
} 
${ }^{8}$ RCMA, MSS3/R3395a/Folder 919/Box 21, Letter from John Underhill, John Walter Thompson, to Richard S Reynolds Jr, 27 December 1946.

${ }^{9}$ RCMA, MSS3/R3395a/Folder 919/Box 21, Letter from John Underhill, John Walter Thompson, to Richard S Reynolds Jr, 27 December 1946; Letter from RSR Sr to Keen Johnson, 29 July 1946.

${ }^{10}$ Perchard, Aluminiumville.

" Recently Mark Wilson has downplayed both Reynolds and Kaiser's gains, suggesting that they did not realise their success in aluminium production until the mid-1950s, which fails to appreciate the considerable barriers to entry to this capital-intensive and closed industry and therefore the full magnitude of Reynolds achievement especially: Wilson, Destructive Creation, 185, 26I-2.

${ }^{12}$ Dudziak, War Time.

${ }^{13}$ Higgs, Crisis and Leviathan, Table 2.I.

${ }^{14}$ Sparrow, Warfare State, 6.

${ }^{15}$ Wilson, Destructive Creation, 2.

${ }^{16}$ Anderson, Aluminium for Defense, 3: for demand and consumption of aluminum, see: Grinberg and HachezLeroy, Industrialisation et sociétés, Annex I.I, I.2, 2.I and 2.2.

${ }^{17}$ Ingulstad, "We want aluminum"; Tiffany, The Decline of American Steel.

${ }^{18}$ FDR suggested in 1943 that "Dr. New Deal" had been replaced by "Dr. Win the War". Bartels suggests that this overstates the shift: "The Office of Price Administration".

${ }^{19}$ Brinkley, "The Idea of the State".

${ }^{20}$ Freyer, Regulating Big Business, 168, 221; Tiffany, The Decline of American Steel, 28, 48.

${ }^{21}$ The historiography of the aluminum industry is vast. For e.g.: Campbell, Global Mission; Smith, From Monopoly to Competition; Grinberg and Hachez-Leroy, Industrialisation et sociétés; Frøland and Ingulstad, From Warfare to Welfare; Perchard, Aluminiumville; Gendron et al, Aluminum Ore; Bertilorenzi, The International Aluminium Cartel; Storli, "Cartel Theory and Cartel Practice".

${ }^{22}$ Balogh, 'Reorganizing the Organizational Synthesis'; Brinkley, "The Idea of the State”; Brinkley, The End of Reform; Neuse, Lilienthal; McKean, Tommy the Cork.

${ }^{23}$ For e.g., Sparrow, World War II; Wilson, Destructive Creation; Scranton, The Second Wave; Badger, New Deal, New South.

${ }^{24}$ For e.g., Rose, "Beyond Buddenbrooks"; Lawton et al, "Corporate Political Activity"; Hillman et al, "Corporate Political Activity”; Frynas et al, "Non-market social and political strategies"; Lawton et al, Aligning for Advantage; Mellahi et al, "A Review of the non-market strategy literature".

${ }^{25}$ Milbrath, Washington Lobbyists; McGrath, "50 Years On”. 
${ }^{26}$ Adams, Mr. Kaiser, 2; Foster, Henry J. Kaiser; Unlike Kaiser, RMC has received limited attention, see references in: Bertilorenzi, The International Aluminium Cartel; Ingulstad, "We want aluminum"; The International Aluminium Cartel.

${ }^{27}$ lbid, 2-3.

${ }^{28}$ See, for example, Ingulstad, "National Security Business" and Bertilorenzi's reference to a profile in Fortune in 1953; see also: Pete Martin, I Call on the Reynolds Brothers (196I), RMC, The Reynolds Wrap Story (1977), and before this RSR Jnr's Opportunity in Crisis, RMAC, RSR Sr papers, MSS3 R3395a, Series I, Folders I and 8.

${ }^{29}$ Adams, Mr. Kaiser, 8.

${ }^{30} \mathrm{lbid}, 3$.

${ }^{31}$ RMAC, MSS3/Series I/Folder 56, RMC, Annual Report, 194I, 1944; For RMC proportion of RFC/ DPC loans (with thanks to Price V. Fishback for making this available to me): US Treasury, Reconstruction Finance Corporation, 83.

${ }^{32}$ Wilson, Destructive Creation.

${ }^{33}$ Badger, New Deal, New South; Foster, Kaiser.

${ }^{34}$ Bensel, Sectionalism and American Political Development, 24I, quoted in Hooks, "Guns and Butter", 257.

${ }^{35} \mathrm{lbid}$.

${ }^{36}$ Tilley, The R. J. Reynolds Tobacco Company.

${ }^{37}$ Adams, Mr. Kaiser, 104; McKean, Tommy the Cork.

${ }^{38}$ For critical reviews see: Robertson in The Journal of American History (March 1989), Clawson in Contemporary Sociology (July 1989).

${ }^{39}$ Galambos, 'The Emerging Organizational Synthesis'.

${ }^{40}$ Idem, 'Technology, Political Economy, and Professionalism'.

${ }^{41}$ Hogan, 'Corporatism', I54; Ellis Hawley, ‘Discovery and Study of a Corporate Liberalism'; McQuaid, Big Business and Presidential Power.

${ }^{42}$ Balogh, 'Reorganizing the Organizational Synthesis'; Brinkley, The End of Reform; Sparrow, World War II; Wilson, Destructive Creation.

${ }^{43}$ Balogh, 'Reorganizing the Organizational Synthesis'; Brinkley, The End of Reform.

${ }^{44}$ Smith, From Monopoly to Competition; Freyer, Regulating Big Business.

${ }^{45}$ John, Network Nation, p.4I3; see also: Smith, From Monopoly to Competition; Tiffany, Decline of American Steel; John, Network Nation.

${ }^{46}$ Scranton, The Second Wave; Badger, New Deal, New South; Cebul, “'They Were the Moving Spirits”; PhillipsFein, Invisible Hands; Phillips-Fein and Zeliser, What's Good for Business; John and Phillips-Fein, Capital Gains. 
${ }^{47}$ Hachez-Leroy, L’Aluminium français; Perchard, Aluminiumville; Bertilorenzi, The International Aluminium Cartel; Storli, "Cartel Theory and Cartel Practice"

${ }^{48}$ Grinberg and Hachez-Leroy, Industrialisation et sociétés; Frøland and Ingulstad, From Warfare to Welfare;

Perchard, Aluminiumville.

${ }^{49}$ lbid.

${ }^{50}$ Mellahi et al, "non-market strategy literature"; For a summary of these criticisms in relation to strategy, see: Perchard et al, "Clio".

${ }^{51}$ Maclean et al, "Hilton", 786.

${ }^{52}$ Bourdieu, "Forms of capital", 249.

${ }^{53}$ Portes, "Social capital".

${ }^{54}$ Bourdieu, "The social space”, 724.

${ }^{55}$ Larson, "Network dyads"; Doh et al, "Nonmarket strategy".

${ }^{56}$ Haggerty, 'Merely for Money', 73.

${ }^{57}$ Phillips-Fein and Zeliser, What's Good for Business, 9; Lane, "Theories and Issues”.

${ }^{58}$ RCMA, MSS3/R3395a/Box 8, Memo from Ed. S. Rogers, Fulton Sylphon, to Earl Chapin May, RMC, 26

October 1945.

${ }^{59}$ Gillespie, Katherine and R. J.; Tilley, The R. J. Reynolds Tobacco Company; For personal insights into the tobacco Reynolds see: Reynolds and, The Gilded Leaf.

${ }^{60}$ Freyer, Regulating Big Business, 33, III, II9.

${ }^{61}$ Wilson, Destructive Creation; John, Network Nation, 399.

${ }^{62}$ Hamilton, Lister Hill.

${ }^{63}$ Haggerty, 'Merely for Money', 73.

${ }^{64}$ Gillespie, Katherine and R. J., 28-33.

${ }^{65}$ Tilley, Gillespie, Katherine and R. J.; Tilley, The R. J. Reynolds Tobacco Company.

${ }^{66}$ Woolcock, "The place of social capital", 13-14.

67 "David Reynolds"; "Miss Clark".

${ }^{68}$ Brinkley, "The New Deal".

${ }^{69}$ Neuse, Lilienthal.

${ }^{70}$ Lipartito, "What Have Lawyers Done for American Business?", 489.

${ }^{71}$ Irons, New Deal Lawyers, x, 5-6

72 Tilley, R. J. Reynolds Tobacco, 29I.

${ }^{73}$ Smith, From Monopoly to Competition; Tiffany, The Decline of American Steel, 8. 
${ }^{74}$ RMCA, MSSI/R3692a/Folder 5, Walter L. Rice Papers, Staff News of the Antitrust Division, Volume I, No.24, 30 November 1936, 7.

${ }^{75}$ RMCA, MSSI/R3692a/Folder 7, Walter L. Rice Papers, Letter from Walter L. Rice to Wright Patman, 5 October 1938.

${ }^{76}$ Lipkowitz was not a lawyer, as Bertilorenzi claims (2015: 267), but an economist: Smith, From Monopoly to Competition, 205-7; Ironically Lipkowitz remained much more wedded as an economist to arguments in line with Arnold over antitrust and efficiency. See, for example, Lipkowitz, 'Conglomerates and Business Competition', 42-44.

${ }_{77}$ Walker, Thurman Arnold, 80-I; According to Tony Freyer this renewed sense of purpose and change in antitrust philosophy from a moral objection to monopolies to arguments based on economic efficiency came to a head in the case against Alcoa after 1945: Regulating Big Business, 22I-2.

${ }^{78}$ RCMA, RSR Jr papers, Box 37/Folder I4I7, Letter from RSR Jnr to Hon. A. Willis Robertson, 26 July 1949; The Manassas Journal, 22 August 1935, I; Swain, Pat Harrison, 198.

${ }^{79}$ Galambos and Pratt, Corporate Commonwealth, 48-52, 120-22, I46-7; Freyer, Regulating Big Business, 89; John, Network Nation, 343-6.

${ }^{80}$ Hamilton, Lister Hill, 90; Swain, Pat Harrison, 198.

${ }^{81}$ Bertilorenzi, The International Aluminium cartel, 236-240.

${ }^{82}$ RCMA, Box 18/Series 4.3/Folders 614, 615, and 654, Marion M. Caskie and Washington Office folders, Richard S Reynolds Jr papers.

${ }^{83}$ RCMA, RSR Jr papers, Box 91/Folder 919, Letter from Keen Johnson to Richard S Reynolds Jr, 8 November 1946.

${ }^{84}$ RCMA, RSR Jr papers, Box 33/Folder 1295, Letter from Marion M. Caskie to RSR Snr, I 3 January 1949.

${ }^{85}$ RCMA, RSR Jnr papers, Box 75/Folder 2663, Letter from Lister Hill to RSR Jnr, 9 June 1956; “Edd Hyde Dies”, Washington Post, December 18, 1997.

${ }^{86}$ Haggerty, "Merely for money", 73.

${ }^{87}$ Lyndon Baines Johnson needs no introduction. Aside from being President and VP, Johnson was a powerful majority and minority leader in both Houses. John Brevard Russell (I897-197I), Governor of Georgia (193I-33), US Senator (1933-1971), Naval Affairs and Armed Services Committee, Joint Committee on Atomic Energy, and CIA congressional oversight committee. John Sparkman (I899-1985), Congressman (1937 - 1946), Senator (1946-79), Congressional majority whip (1946), Chairman, Senate Select Committees on Small Business (1955- 
67), Banking, Housing, and Urban Affairs (1967-75), Foreign Relations (1975-79), and Adlai Stevenson's VicePresidential running mate in 1952. Carl Vinson (1883-1981), Congressman (1914-1965), Chairman, House Naval Affairs Committee (1931-47), Chairman, House Armed Services Committee (1949-53, 1955-65). John L. McClellan (1896-1977), Congressman (1935-9), Senator (1943-77), and Chairman of the Senate Appropriations Committee (1972-77). Estes Kefauver (1903-63), Congressman (1939-49), and Senator (1949-63). J. William Fulbright (1905-1995), Congressman (1943-5), Senator (1945-74), Chairman, Senate Committees on Banking and Currency (1955-9) and Foreign Relations (1959-74). Joseph Lister Hill (1894-1984), Congressman (1923-38), Senator (1938-69), majority whip US Senate (194I-7), Chairman, Labor and Public Welfare Committee (195569). For their continued influence, see: Badger, New Deal, New South; McKinstry, We Shall Overcome; Klimas, “Building Consensus”; Dallek, Johnson; Hamilton, Lister Hill; Fite, Russell; Woods, Fulbright.

${ }^{88}$ See, for e.g.: "Reynolds Says Hill Staved Off Metals Shortage”, Montgomery Advertiser, October 24, I94I; Hamilton, Lister Hill.

${ }^{89} \mathrm{lbid}, 63$.

${ }^{90}$ RCMA, RSR Jr papers, Box 53/Folder 1970, Interdepartmental correspondence from John Krey to RSR Jnr, 27 March 1952.

${ }^{91}$ US Library of Congress, Harold L. Ickes papers, Folder 82, Letter from Ickes to RSR Jr, 9 October 1950.

${ }^{92}$ Ibid, 233.

${ }^{93}$ For e.g. Drew Pearson, “The Washington Merry-Go-Round”, The Washington Post, 27 November 195 I.

${ }^{94}$ Library of Congress, Harold L. Ickes papers, Folder 82, Letter from Marion M. Caskie to Harold L. Ickes, I I January 1951.

${ }^{95}$ RCMA, RSR Jr papers, Box 20/Folder 6/4, 'Liaison activities', Memo from RMC Washington Office to RMC, 16 June 1944.

${ }^{96}$ RCMA, RSR Jr papers, Box 18/Folder 614, Letter from J. T. Jones, US Army, to W.T. Brunot, RMC, I3 July 1944.

${ }^{97}$ RCMA, RSR Jr papers, Box 20/ Folder 720, Programme for 'Production for Total Victory', Philadelphia Post of the Army Ordnance Association, 5 February 1945.

${ }^{98}$ RCMA, RSR Jr papers, Box 18/ Folder 614, Memo from G. E. Stansbury, RMC Washington, to RSR Jnr., I September 1944.

${ }^{99}$ Adams, Mr Kaiser, 10-11.

${ }^{100}$ RCMA, RSR Jr papers, Box 31/Folder 1206, Note from Donald A. White to RSR Jnr, n.d., 1948. 
${ }^{101}$ Cebul, "They Were the Moving Spirits".

102 RCMA, RSR Snr papers, Box 6/ Folder: Correspondence on Milledgeville Naval Ordnance Plant (1942-5), Letter from RSR Snr to Sen. Russell, 19 October 1945.

${ }^{103}$ Fite, Russell.

${ }^{104}$ Reedy, The U.S. Senate, 3I, quoted in Klimas, "Balancing consensus", 53.

${ }^{105}$ Quoted in lbid, 55.

${ }^{106}$ RCMA, RSR Jr papers, Box 20/Folder 720, Letter from Keen Johnson to RSR Jnr, 16 March 1945; Cook, Vinson.

${ }^{107}$ RCMA, RSR Jr papers, Box 38/Folder I467, Letters from Keen Johnson to RSR Jnr, I3 January and 8 March 1949.

${ }^{108}$ Olsen privileges, and overstates, Symington's part in breaking Alcoa's monopoly: Olsen, Stuart Symington, 69-7I, 215.

${ }^{109}$ Woods, Fulbright.

110 RCMA, RSR Jr papers, Box 27/Folder 1026, Letter from Walter L. Rice to RSR Jr, 22 May 1947; Letter from Walter L. Rice to Irving Lipkowitz, 13 May 1947.

I'I RCMA, RSR Jnr papers, Box 27/ Folder 1026, Letter from L. M. Brile, Fairmont Aluminum Co., to RSR Jr, 27 June 1947.

112 RCMA, RSR Jnr papers, Box 3।/ Folder II89, Letter from Walter L. Rice to Donald M. White, AA, 7 February 1947.

${ }^{113}$ RCMA, RSR Jnr papers, Box 31/ Folder I I89, Letter from RSR Jr to all committee members, 18 July 1947.

${ }^{114}$ RCMA, RSR Jr papers, Box 28/Folder I1 00, Memo of meeting between RMC and Kaiser Aluminum, 30 July 1947.

${ }^{115}$ RCMA, RSR Jnr papers, Box 3 I/ Folder I 189, Dusty Rhoades, Kaiser Aluminum, response to "Chief" Wilson, 2 September 1947; Letter from W. A. Singer to "Chief" Wilson, 9 September 1947; Letter from RSR Jr to Wilson, (undated) September 1947; Wilson to Committee members, 25 September 1947.

116 Ingulstad, “National Security Business?", II4.

${ }^{117}$ Ingulstad, "Winning the Hearth and Mines", 72, 254-5.

${ }^{118}$ Perchard, Aluminiumville, 98-99; Evenden, Fish versus Power, 167-8. 
${ }^{119}$ RCMA, , RSR Jr papers, Box 38/Folder I467, Letter from KJ to RSR Jr (enclosing transcript of evidence), 20 September 1949; Letter from KJ to RSR Jnr with note of advance meeting with Senator Lister Hill, I I September 1949.

${ }^{120}$ RCMA, RSR Jr papers, Box 48/Folder I787, Letter from Caskie to Lipkowitz, 26 October 195 I.

${ }^{121}$ RCMA, RSR Jr papers, Box 84/Folder 2955, Letter from RSR Jnr to Fulbright, 3 March 1958.

${ }^{122}$ RCMA, RSR Jnr papers, Box 91/Folder 3188, RSR Jr. to M. A. Robertson, Ambassador of Canada, 2 April 1958; Note of meeting of Reynolds T. I. Aluminium Ltd, 25 November 1959; McKeever, Adlai Stevenson, 342-3, 401.

${ }^{123}$ RCMA, RSR Jnr papers, Box 218/Folder 4289, Letter from Caskie to RSR Jr, 12 April I95I, RSR Jnr papers, same loc.

${ }^{124}$ LBJ Library, Papers of Lyndon Baines Johnson, White House Central Files: President, 1963-1969, Box 8, Meeting between Richard S. Reynolds Jr, Robert B. Anderson, Joseph McConnell, Reynolds Metals, and President Lyndon Baines Johnson, 5 October 1965.

125125 LBJ Library, Papers of Lyndon Baines Johnson, White House Central Files: President, I963-1969, Boxes I (CM/Commodities and CM/ Aluminum folders) and 7 (CM/Aluminum folder). For example, Box I, CM/ Commodities folder, Memo from Joseph A. Califano Jr, White House Advisor, to John W. Douglas, 'Actions taken and actions proposed to stabilize prices', 28 December 1965.

${ }^{126}$ LBJ Library, Telegram from RSR Jnr to LBJ, 24 January 1968; Letter from Joseph Califano, Jnr, to RSR Jnr, 3 I January 1968.

${ }^{127}$ Badger, New Deal, 69.

${ }^{128}$ RCMA, RSR Jnr papers, Box 48/Folder 1799, Letter from Patterson, Belknap and Webb, to RSR Jnr, 31 July 1951; Launch of the 195I NAACP Legal Defense and Educational Fund.

129 “Major Reynolds", The Washington Post, 20 April 1977; McCutcheon and Gleason, Sarge Reynolds.

${ }^{130}$ Reynolds, "Opportunity in Crisis", 2.

131 "Major Reynolds".

132 RCMA, RSR Jr papers, Folder 919/Box 2I, Letter from RSR Sr to Keen Johnson, 29 July 1946.

${ }_{133}$ Mary B. Rose, "Beyond Buddenbrooks," in Entrepreneurship. 